\title{
Diversity and Abundance Dragonflies (Odonata) at Mount Sigogor Nature Reserve Area, Ponorogo Regency, East Java, Indonesia
}

\author{
Muhamad Azmi Dwi Susanto*, Saiful Bahri \\ Biology Departement, Faculty Sains dan Technologi, UIN Sunan Ampel Surabaya Jl. A. Yani 117, \\ Surabaya, Jawa Timur, Indonesia \\ *email: Muhammadazmidwi@gmail.com
}

Article Info

Keyword:

Diversity

Dragonflies

Nature Reserve

Article history:

Received: 03/05/2021

Revised: 09/07/21

Accepted: 13/07/21

\begin{abstract}
Mount Sigogor Nature Reserve area is a mountainous tropical rain forest, administratively located in Pupus Village, Ngebel District, Ponorogo Regency, East Java, Indonesia. One of the main functions of this nature reserve is as a water catchment area for the villages around the nature reserve area. Water sources and flows within the Mount Sigogor Nature Reserve area have the potential as natural habitat for dragonflies. This study aims to determine the diversity and abundance of dragonflies (Odonata) in the Mount Sigogor Nature Reserve Area. The method of collecting dragonflies data used the Visual Day Flying method by recording the diversity of dragonflies species and counting the number of individuals from each observed dragonflies species. The data obtained were analyzed using the Relative abundance, Shannon-Wiener Heterogeneity Index and the frequency of Presence. The results of the research conducted showed that there were 14 species from 7 families with a total of 464 individuals. The Shannor-Wiener diversity index shows that the diversity value is $H^{\prime}=1.81$. Meanwhile, the presence frequency analysis showed that there were four species with a value of $100 \%$ which were classified as abundant Frequency of Presence, namely Euphaea variegata, Vestalis luctuosa, Rhinocypha anisoptera and Coeliccia membranipes.
\end{abstract}

Copyright $@ 2021$ Author(s). All Right Reserved

\section{Introduction}

Dragonflies are a group of insects that are small to large and mostly attractively colored, based on the scientific classification of dragonflies in the Order Odonata. Dragonflies undergo incomplete metamorphosis. There are three phases in the dragonfly life cycle, namely egg, naiad and adult dragonfly stages. The egg and naiad phases of aquatic dragonflies and their terrestrial adult phase (Laily et al., 2018). Most of the dragonfly life is spent in the naiad phase, namely in the water, the dragonfly naiad phase takes one month to years before becoming an adult dragonfly (Paulson, 2009). Therefore, in the vicinity of the aquatic ecosystem, most of them become natural habitats for various types of dragonflies.

The diversity and abundance of dragonflies is very important for the ecosystem, this is because dragonflies have a major role in maintaining the balance of the food chain and act as predators of small insects in the nymph and adult phases. Small insects that fall prey to dragonflies are mosquitoes, flies, fleas to agricultural pests (B. C. Pamungkas, 2016). Thus it shows that the diversity and abundance 
of dragonflies in an ecosystem can be an indicator of ecosystem balance (D. W. Pamungkas \& Ridwan, 2015). In addition to maintaining the balance of the food chain, the diversity and abundance of dragonflies can also be used as bioindicators of environmental quality. Dragonflies have high sensitivity to pollution and will leave their habitat if there is damage to the environment that is their natural habitat. This is because dragonflies have an organ that functions as a detector of chemical compounds in the surrounding environment, namely the olfactory sensor nerves contained in the antenna. This causes dragonflies to be used as bioindicators in the environment, especially water quality (Nugrahani et al., 2014).

The Mount Sigogor Nature Reserve Area is administratively located in Pupus Village, Ngebel District, Ponorogo Regency, East Java, Indonesia. The Mount Sigogor nature reserve is a mountainous tropical rain forest area that has a water source that flows from the area to the village stream. One of the main functions of this nature reserve is as a water catchment area for the villages around the nature reserve area. Water sources and flows within the Mount Sigogor Nature Reserve area have the potential as natural habitat for dragonflies. There was no data on the diversity and abundance of dragonflies at Mount Sigogor Nature Reserve area making this study very important. This study aims to determine the diversity and abundance of dragonflies in the Mount Sigogor Nature Reserve Area.

\section{Materials and Methods}

This research was conducted on 20 January - 20 February, 2021 with observation time at 08.00-13.00 WIB. This research was conducted in the Nature Reserve of Mount Sigogor, Pupus Village, Ngebel District, Ponorogo Regency, East Java, Indonesia. The location of the Mount Sigogor Nature Reserve is divided into several observation locations based on the composition of vegetation, differences in habitat, position of stream and ease of access. Based on the position of the stream, five observation locations were made scattered at various points in the Mount Sigogor Nature Reserve area. The selection of these seven locations was also based on differences in the composition of vegetation in the location and the ease of access to the location.
The tools and materials used in this research are GPS, stationery, cameras, watches, insect nets and identification books (Orr, 2005; B. C. Pamungkas, 2016; Setiyono et al., 2017).

The method of collecting dragonfly data used the Visual Day Flying method by recording the diversity of dragonfly species and counting the number of individuals from each observed dragonfly species. Data collection is carried out at 08:00 - 13:00 WIB. Observations were made in the morning because it was the time the dragonflies were active. The types of dragonflies observed were documented using a camera and identified using the identification book (Orr, 2005; B. C. Pamungkas, 2016; Setiyono et al., 2017). Data recording includes types and numbers of dragonflies.

The data on dragonflies obtained were then analyzed using the Relative Abundance (RA) (Suaskara \& Joni, 2020) and Shannon-Wiener index based on (Laily et al., 2018) with the following formula.

Relative Abundance:

$$
R A=\frac{n i}{N} \times 100 \%
$$

Diversity Index:

$$
H^{\prime}=\sum\left(\frac{n i}{N} \operatorname{In} \frac{n i}{N}\right)
$$

Note:

RA : Relative Abundance

$H^{\prime}$ : Shannon-Wiener Diversity Index

ni : Total individuals belonging to the $\mathrm{i}$ species

$\mathrm{N}$ : Total individuals of population

The results of data on the number of species and individuals are calculated the frequency of presence using the following formula.

$$
\mathrm{PF}=\frac{\text { Total posts found species } i}{\text { the total of posts }} \times 100 \%
$$

\section{Results and Discussion}

The results of research conducted in the Mount Sigogor Nature Reserve area showed that there were 14 species from 7 families consisting of 5 species of Suborder Zygoptera and 9 species of Suborder Anisoptera. The number of individuals found was 464 individuals, of which 349 individuals belonged 
to Suborder Zygoptera and 115 individuals belonged to Suborder Anisoptera (Table 1). In this study, species Vestalis luctuosa was dragonfly with the highest number, namely 171 individuals with relative abundance $36.85 \%$, while dragonfly with the least number was Zygonyx iris with 1 species with relative abundance $0.22 \%$.

The Vestalis luctuosa species is a Zygoptera damselfly with a large size, male species dominated by metallic blue on the thorax, legs, abdomen and wings. The wings and legs have a darker metallic blue color. Whereas in female species the thoracic part is dominated by metallic green, on the abdomen and metallic brown wings (Setiyono et al., 2017). Vestalis luctuosa Damselfly is often found in habitats with dense or open vegetation. This species can be found in forest streams that have clean water flows with slow to swift currents (Aswari, 2004). In this study, the species of Vestalis luctuosa were often found during the day with perch on leaves or twigs. The stream in the Mount Sigogor Nature Reserve, which has clean water and vegetation conditions where there are many herbaceous plants on the stream side, is thought to be the main factor causing the abundance of Vestalis luctuosa species.

The Zygonyx iris dragonfly has dark green metallic on the thorax and metallic brown abdomen. This dragonfly has a color similar to the species Zygonyx ida. On each segment of the abdomen there is a yellow color that is shaped like a ring and there is a line in the middle of the abdomen that extends to the end. Females have a color that is not much different from male (Orr, 2005). Zygonyx iris species are usually found in mountain streams with slightly open canopies and will approach the water when the weather is clear. When above water this species will fly low near waterways in search of prey. In this study, the Zygonyx iris species were often found flying during the day near streams where there were few trees for foraging and mating. The habitat type in the Mount Sigogor Nature Reserve, which mostly has a closed canopy, is thought to be the main factor causing the very few Zygonyx iris species.

Table 1. List of species, Amount of individuals and Conservation Status

\begin{tabular}{|c|c|c|c|c|c|c|c|c|}
\hline \multirow{2}{*}{ Sub ordo - Familia - Species } & \multicolumn{6}{|c|}{ Amount } & \multirow{2}{*}{$\begin{array}{c}\text { Relative } \\
\text { Abundance }\end{array}$} & \multirow{2}{*}{$\begin{array}{c}\text { Conservation } \\
\text { status }\end{array}$} \\
\hline & $\mathbf{L 1}$ & $\mathbf{L 2}$ & $\mathbf{L 3}$ & L4 & L5 & Total & & \\
\hline \multicolumn{9}{|l|}{ Zygoptera } \\
\hline \multicolumn{9}{|l|}{ Euphaeaidae } \\
\hline Euphaea variegata & 19 & 33 & 3 & 3 & 35 & 93 & 20.04 & LC \\
\hline Calopterygidae & & & & & & & 3685 & $\mathrm{I} C$ \\
\hline Vestalis luctuosa & 32 & 54 & 17 & 11 & 57 & 171 & 30.85 & LC \\
\hline Clorocyphidae & & & & & & & & \\
\hline Heliocypha fenestrata & & & & & 2 & 2 & 0.43 & LC \\
\hline Rhinocypha anisoptera & 1 & 4 & 3 & 6 & 22 & 36 & 7.76 & $\mathrm{LC}$ \\
\hline Platycnemididae & & & & & & & & \\
\hline Coeliccia membranipes & 20 & 14 & 5 & 4 & 4 & 47 & 10.13 & $\mathrm{LC}$ \\
\hline \multicolumn{9}{|l|}{ Anisoptera } \\
\hline \multicolumn{9}{|l|}{ Cordulidae } \\
\hline Idionyx montana & & & 1 & & 6 & 7 & 1.51 & DD \\
\hline $\begin{array}{l}\text { Gomphidae } \\
\text { Heliogomphus drescheri }\end{array}$ & 1 & & & & 1 & 2 & 0.43 & $\mathrm{NE}$ \\
\hline Nepogomphus frushtorferi & & & & & 2 & 2 & 0.43 & NT \\
\hline Libellulidae & & & & & & & 086 & I C \\
\hline Orthetrum glaucum & 1 & & & & 3 & 4 & 0.80 & LC \\
\hline Orthetrum pruinosum & 3 & & & & & 3 & 0.65 & $\mathrm{LC}$ \\
\hline Orthetrum sabina & 10 & & 1 & & 4 & 15 & 3.23 & $\mathrm{LC}$ \\
\hline Pantala flavescens & 72 & & & & & 72 & 15.52 & $\mathrm{LC}$ \\
\hline Zygonyx ida & & 3 & 1 & & 5 & 9 & 1.94 & $\mathrm{LC}$ \\
\hline Zygonyx iris & 1 & & & & & 1 & 0.22 & $\mathrm{LC}$ \\
\hline Total & 160 & 108 & 31 & 24 & 141 & 464 & & \\
\hline
\end{tabular}




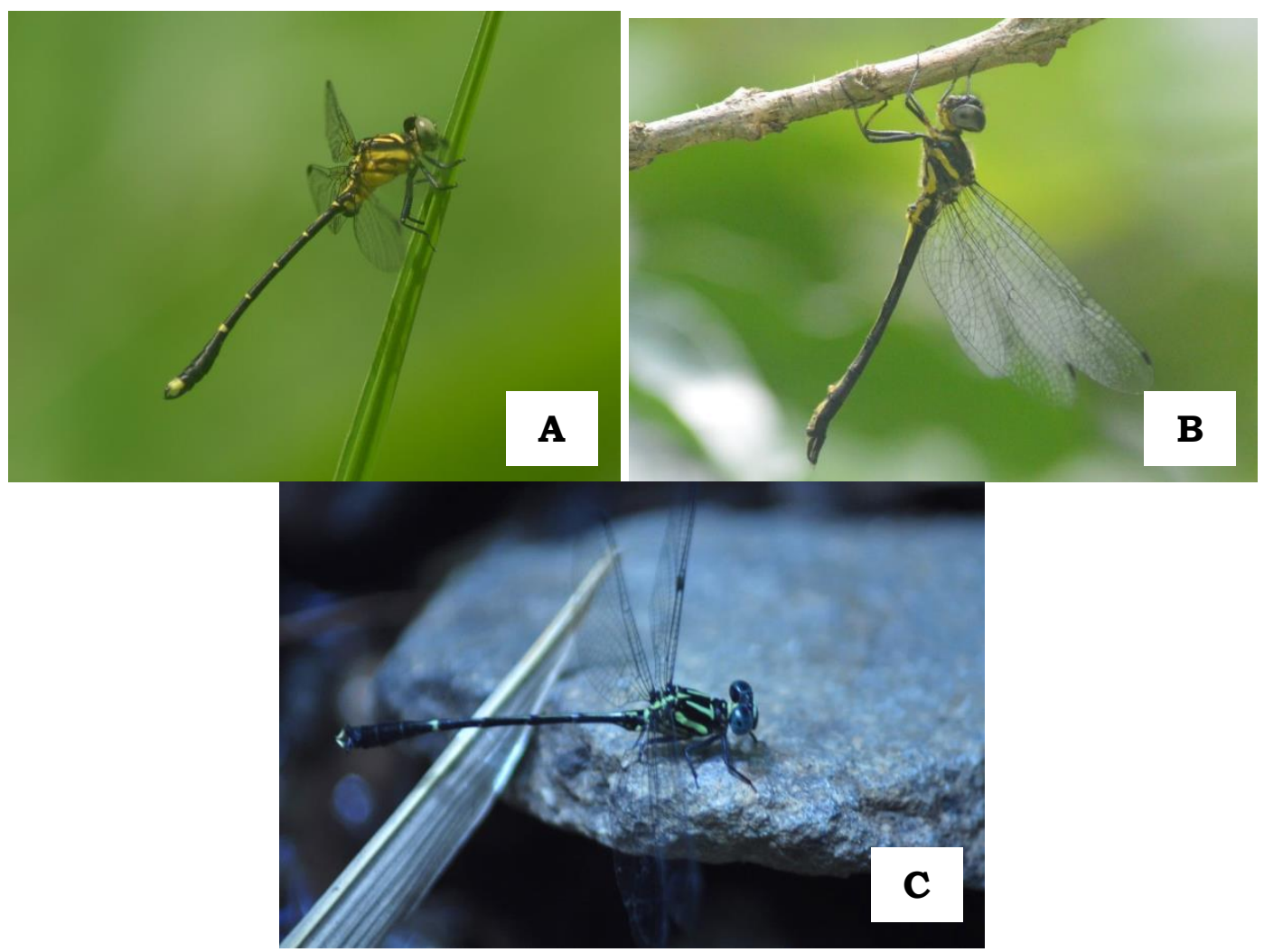

Figure 1. Photo Dragonflies A). Nepogomphus frushtorferi, B). Idionyx montana, C). Heliogomphus drescheri.

Based on data from the International Union of Conservation Nature, in this study there is one species that is in the near threatened (NT) category, namely the Nepogomphus fruhstorferi species (Dow, 2020). One other species is categorized as Data Deficient (DD), namely Idyonix montana species (Dow, 2009), and one species that is not evaluated (NE) category, namely the Heliogomphus drescheri species

The Nepogomphus fruhstorferi (Figure 1A) belongs to near threatened (NT) category, this dragonfly scattered in various places in Java, and Sumatra (Indonesia) and Malaysia (Dow, 2020) Nepogomphus fruhstorferi species is yellow with a black stripe on the thorax, the abdomen is predominantly black with yellow rings on each segment on S3-S6. This species has gray-green compound eyes. This species is a small Suborder Anisoptera dragonfly (Orr, 2005). The Nepogomphus fruhstorferi species is often found perching on leaves and twigs in open vegetation, this species can be found in clear water flows in forests with an altitude of 100-650m (Orr, 2005). In this study, Nepogomphus fruhstorferi species are often found perched on tree branches near streams.

The Idionyx montana (Figure 1B) belongs to data deficient (DD) category, this dragonfly scattered in various places in Sumatra and Java (Indonesia) and Malaysia (Dow, 2009), Idionyx montana species has bright green eyes. Dominated by green metallic with yellow stripes on the thorax, black abdomen with a slender shape. Females have a pattern and color similar to male, but with a paler color (B. C. Pamungkas, 2016). The Idionyx montana species is often found flying high above watercourses. This dragonfly has a habitat where there are many trees with denser vegetation (Abdillah, 2018). This species is often found flying near streams in the morning to noon, with many trees around the stream flow site.

The Heliogomphus drescheri (Figure 1C) belongs to not evaluated (NE) category, this dragonfly not listed in IUCN. Heliogomphus drescheri species has compound eyes with a turquoise color. dominated by black color with light green stripes on the thorax, black on the abdomen and slender on the S1-S7 and 
enlarged on the S8-S10. The dorsal bulb is widened and then the tip is curved inward. This anisoptera dragonfly is medium in size (Abdillah, 2018). This species is often found perching on rocks located around stream flows. This species is often found in habitats with lots of bamboo and bushes and in denser vegetation (Abdillah, 2018). In this study, the Heliogomphus drescheri species were found perching on rocks in the middle of a stream with denser canopy.

In the value of Frequency of Attendance, if it shows a value of $0-25 \%$ it is classified as very rare, a value of $25-50 \%$ is classified as rare presence, a value of $50-75 \%$ is classified as moderate presence, and if a value of $75-100 \%$ is classified as an abundant presence level (Barus, 2004). The results of the calculation of the frequency of the presence of dragonflies in the Mount Sigogor Nature Reserve Area are as follows.

\section{Table 2. Presence Frequency}

\begin{tabular}{lcl}
\hline \multicolumn{1}{c}{ Species } & $\begin{array}{c}\text { Presence } \\
\text { Frequen } \\
\text { cy } \mathbf{( \% )}\end{array}$ & Presence \\
\hline Euphaea variegata & 100 & Abundant \\
Vestalis luctuosa & 100 & Abundant \\
Heliocypha fenestrata & 20 & Very rare \\
Rhinocypha anisoptera & 100 & Abundant \\
Coeliccia membranipes & 100 & Abundant \\
Idionyx montana & 40 & Rare \\
Heliogomphus drescheri & 40 & Rare \\
Nepogomphus frushtorferi & 20 & Very rare \\
Orthetrum glaucum & 40 & Rare \\
Orthetrum pruinosum & 20 & Very rare \\
Orthetrum sabina & 60 & Moderate \\
Pantala flavescens & 20 & Very rare \\
Zygonyx ida & 60 & Moderate \\
Zygonyx iris & 20 & Very rare \\
\hline
\end{tabular}

Index on Presence Frequency is abundant with a value of $100 \%$ found in four species, namely Euphaea variegata, Vestalis luctuosa, Rhinocypha anisoptera and Coeliccia membranipes (Table 2). These four species of Suborder Zygoptera were found in all observation posts, this indicates that there are similarities in the habitat types of the five posts so that the four species are found in all observation posts. According to (Aswari, 2004), the species of Vestalis luctuosa and Euphaea variegata have similar habitats and types of food. Rhinocypha anisoptera,
Euphaea variegata and Vestalis luctuosa species are often found flying together (Abdillah \& Lupiyaningdyah, 2020). Whereas the Coeliccia membranipes species have habitats that have a denser canopy and high humidity (Setiyono et al., 2017).

The frequency of presence was very rare with a value of $20 \%$, five species were found, namely Heliocypha fenestrata, Nepogomphus frushtorferi, Orthetrum pruinosum, Pantala flavescens and Zygonyx iris (Table 2). These five species were only found at one of the five observation posts, this shows that there are different habitat types of each species and limited habitat conditions at the observation posts. The Heliocypha fenestrata and Nepogomphus frushtorferi species are only found at the L5 observation post, this location has a large stream flow with rocks in the middle of the flow so that it becomes a suitable habitat for Heliocypha fenestrata species and has an open canopy condition with lots of trees so that it becomes a suitable habitat for Nepogomphus frushtorferi species.

Whereas the Orthetrum pruinosum, Pantala flavescens and Zygonyx iris species were found at the L1 observation post, this location has vegetation conditions that are dominated by herbaceous plants and shrubs with many trees. In the Orthetrum pruinosum species it is often found perching on rocks in open vegetation. Pantala flavescens species have high flight activity in open vegetation, this species has a high tolerance for organic pollution so that it can be found in urban areas. In Zygonyx iris species has almost the same type as Zygonyx ida, but this species is more often found perched on trees.

The diversity index value according to Shannon-Wienner is defined if the value of $H$ 'is more than 0 and less than 1.5 then the diversity value is low, if the value of $H^{\prime}$ is more than 1.5 and less than 3.5 then the diversity value is medium and the value $H$ 'more than 3.5 values of diversity are high (Hartika et al., 2017). The results of the data obtained show the diversity index as follows.

The results of the Shannor-Wiener diversity index analysis show that the diversity value of dragonflies in the Mount Sigogor Nature Reserve is $H^{\prime}=1.81$ (Figure 2), this indicates that the diversity value is classified as 
moderate. The value of the diversity index which is classified as moderate indicates that the environmental conditions of the Mount Sigogor Nature Reserve area are good enough for the survival of dragonflies.

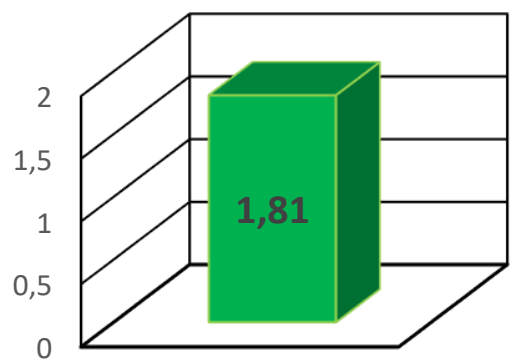

\section{Figure 2. Diversity Index of Shannon- Wiener Mount Sigogor Nature Reserve Area}

The diversity value of dragonflies in the Mount Sigogor Nature Reserve area is smaller than the diversity value of dragonflies (Odonata) in the waters of the Lempake Samarinda Dam, which is $H^{\prime}=2.83$ (Nisita et al., 2020). Meanwhile, the value of dragonfly diversity in the Mount Sigogor Nature Reserve has a higher value than the value of dragonfly diversity in the Selorejo Reservoir, Malang Regency, which is equal to $H^{\prime}=1.7$ (Susanto et al., 2020). The difference in the value of diversity in an area is because each area has different microclimate and vegetation conditions. The main factor that makes differences in dragonfly species diversity in each place is the factor of food resources, habitat, light intensity, temperature and humidity (Herlambang et al., 2016).

The condition of vegetation in a location greatly affects the presence of dragonfly species, this is because dragonflies need vegetation such as sub-layer plants to lay their eggs when reproducing and can be used for perches (Nugrahani et al., 2014). In addition, dragonfly larvae need vegetation on streamside to find food and to protect from predators. In adult dragonflies, the vegetation on the banks of the stream is used for resting and sunbathing (Silva et al., 2010). Vegetation conditions will also affect the state of the canopy in a place, for canopy several types of dragonflies are used to shelter from high intensity sunlight (Nugrahani et al., 2014). While the microclimate in a place is an important factor in providing habitat that supports the sustainability of the dragonfly life cycle (Abdillah et al., 2019), this is because the microclimate affects plants and animals, especially small insects as the main food for dragonflies.

\section{Conclusion}

Based on the results of research conducted in the Mount Sigogor Nature Reserve, there are 14 species from 7 families consisting of 5 species of Suborder Zygoptera damselfly and 9 species of Suborder Anisoptera dragonfly. The results of the Shannor-Wiener diversity index analysis show is $H^{\prime}=1.81$, this indicates that the diversity value is classified as moderate. At the highest Frequency of Presence value, there were four species with a value of $100 \%$ which were classified as abundant Frequency of Presence, namely Euphaea variegata, Vestalis luctuosa, Rhinocypha anisoptera and Coeliccia membranipes. Whereas at the lowest Frequency of Presence value there were five species with a value of $20 \%$ which were classified as very rare, namely Heliocypha fenestrata, Nepogomphus frushtorferi, Orthetrum pruinosum, Pantala flavescens and Zygonyx iris.

\section{Acknowledgment (optional)}

The author would like to thank you to the family of KUTRIK entomology study group and RKW 06, SKW II Bojonegoro, BKSDA I Madiun, BBKSDA Jawa Timur have provided support and assisted in the licensing process to field research. We also thanks to Siti Zulaikha and Nur Qomariyah Pratiwi that helps in data collection.

\section{References}

Abdillah, M. M. (2018). Diversitas Odonata dan Peranannya sebagai Indikator Kualitas Air di Sumber Clangap dan Sumber Mangli Desa Puncu Kecamatan Puncu Kabupaten Kediri [Skripsi, UIN Sunan Ampel Surabaya]. http://digilib.uinsby.ac.id/25829/

Abdillah, M. M., \& Lupiyaningdyah, P. (2020). Distribution, Characteristic and Behavior of Rhinocypha anisoptera Selys, 1879 (Odonata: Zygoptera: Chlorocyphidae in East Java. Zoo Indonesia, 29(2), 94-102. https://doi.org/10.52508/zi.v29i2.4036 
Abdillah, M. M., Prakarsa, T. B. P., \& Tyastirin, E. (2019). Odonata Diversity at Sumber Clangap and Sumber Mangli Puncu Village Sub District of Puncu District of Kediri. Jurnal Biodjati, 4(2), 236-243. https://doi.org/10.15575/ biodjati.v4i2.4823

Aswari, P. (2004). Ekologi Capung Jarum Calopterygidae: Neurobasis chinensis dan Vestalis luctuosa di Sungai Cikaniki, Taman Nasional Gunung Halimun. BERITA BIOLOGI, 7(1 \& 2), 57-63. https://doi.org/10.14203/ beritabiologi.v7i1\&2.1236

Barus, T. A. (2004). Pengantar Limnologi Studi Tentang Ekosistem Air Daratan. USU Press.

Dow, R. A. (2009). Idionyx montana. The IUCN Red List of Threatened Species 2009: $\quad$ E.T163818A5655984. https://dx.doi.org/10.2305/IUCN.UK.2 009-2.RLTS.T163818A5655984.en

Dow, R. A. (2020). Nepogomphus fruhstorferi. The IUCN Red List of Threatened Species 2020: E.T139369530A139404028. https:// dx.doi.org/10.2305/IUCN.UK.20201.RLTS.T139369530A139404028.en

Hartika, W., Diba, F., \& Wahdina, W. (2017). Keanekaragaman Jenis Capung (Odonata) pada Ruang Terbuka Hijau Kota Pontianak. JURNAL HUTAN LESTARI, 5(2), 156-163. https://doi. org/10.26418/jhl.v5i2.18972

Herlambang, A. E. N., Hadi, M., \& Tarwotjo, U. (2016). Struktur Komunitas Capung di Kawasan Wisata Curug Lawe Benowo Ungaran Barat. Bioma: Berkala Ilmiah Biologi, 18(2), 70-78. https://doi.org/10.14710/bioma.18.2.7 $0-78$

IUCN. (2021). The IUCN Red List of Threatened Species. IUCN Red List of Threatened Species. https://www. iucnredlist.org/en

Laily, Z., Rifqiyati, N., \& Kurniawan, A. P. (2018). Keanekaragaman Odonata pada Habitat Perairan dan Padang Rumput di Telaga Madirda. Indonesian Journal of Mathematics and Natural
Sciences, $\quad 41(2), \quad$ 105-110. https://journal.unnes.ac.id/nju/index.p $\mathrm{hp} / \mathrm{JM} /$ article/view/19211

Nisita, R. A., Hariani, N., \& Trimurti, S. (2020). Keanekaragaman Odonata di Kawasan Bendungan Lempake, Sungai Karang Mumus dan Sungai Berambai Samarinda. Edubiotik: Jurnal Pendidikan, Biologi Dan Terapan, 5(02), 123-141. https://doi.org/10. 33503/ebio.v5i02.774

Nugrahani, M. P., Nazar, L., Makitan, T., \& Setiyono, J. (2014). Peluit Tanda Bahaya: Capung Indikator Lingkungan Panduan Penilaian Kualitas Lingkungan Melalui Capung. Indonesian Dragonflies Society.

Orr, A. G. (2005). Dragonflies of Peninsular Malaysia and Singapore / A. G. Orr. Natural History Publications (Borneo). https://www.researchgate.net/publicati on/262685570_Dragonflies_of_Penins ular_Malaysia_and_Singapore

Pamungkas, B. C. (2016). UNTRING: Dragonflies of Banyuwangi. Indonesia Dragonfly Society (IDS).

Pamungkas, D. W., \& Ridwan, M. (2015). Keragaman Jenis Capung dan Capung Jarum (Odonata) di Beberapa Bumber Air di Magetan, Jawa Timur. Prosiding Seminar Nasional Masyarakat Biodiversitas Indonesia, 1(6), 12951301. https://doi.org/10.13057/ PSNMBI/M010606

Paulson, D. (2009). Dragonflies and Damselflies of the West. Princeton University Press.

Setiyono, J., Diniarsih, S., Oscilata, E. N. R., \& Budi, N. S. (2017). Dragonflies of Yogyakarta. Indonesian Dragonflies Society.

Silva, D. de paiva, De Marco, P., \& Resende, D. C. (2010). Adult odonate abundance and community assemblage measures as indicators of stream ecological integrity: A case study. Ecological Indicators, 10(3), 744-752. https://doi.org/10.1016/j.ecolind.2009. 12.004 
Suaskara, I. B., \& Joni, M. (2020). Keanekaragaman Jenis Capung dan Pemanfaatan Nimfanya sebagai Nilai Tambah Pendapatan di Bendungan Latu Abiansemal. SIMBIOSIS, 8(1), 28-33. https://doi.org/10.24843/ JSIMBIOSIS.2020.v08.i01.p04
Susanto, M. A. D., Abdillah, M. M., Permana, R. C., Mubarak, Z., \& Anwar, M. S. (2020). Inventarisasi Jenis Capung (Anisoptera) dan Capung Jarum (Zygoptera) di Sumber Clangap dan Sumber Mangli Kabupaten Kediri dalam Prosiding Seminar Nasional Biologi (SEMABIO) 2020. Pusat Penelitian dan Penerbitan UIN Sunan Gunung Djati Bandung. http://digilib.uinsgd.ac.id/36525/1/PR OSIDING\%20SEMABIO\%205.pdf 